\title{
A meta-analysis of long-term effects of conservation agriculture on maize grain yield under rain-fed conditions
}

\author{
Leonard Rusinamhodzi • Marc Corbeels • \\ Mark T. van Wijk • Mariana C. Rufino • \\ Justice Nyamangara $\cdot$ Kenneth E. Giller
}

Accepted: 23 April 2011 / Published online: 6 July 2011

(C) The Author(s) 2011. This article is published with open access at Springerlink.com

\begin{abstract}
Conservation agriculture involves reduced tillage, permanent soil cover and crop rotations to enhance soil fertility and to supply food from a dwindling land resource. Recently, conservation agriculture has been promoted in Southern Africa, mainly for maize-based farming systems. However, maize yields under rain-fed conditions are often variable. There is therefore a need to identify factors that influence crop yield under conservation agriculture and rain-fed conditions. Here, we studied maize grain yield data from experiments lasting 5 years and more under rain-fed conditions. We assessed the effect of long-term tillage and residue retention on maize grain yield under contrasting soil textures, nitrogen input and climate. Yield variability was measured by stability analysis. Our results show an increase in maize yield over time with conservation agriculture practices that include rotation and high input use in low
\end{abstract}

L. Rusinamhodzi

CIAT-TSBF Harare,

Box MP228, Mt Pleasant, Harare, Zimbabwe

M. Corbeels

CIRAD-Annual Cropping Systems,

C/O Embrapa-Cerrados Km 18,

020 Rodovia Brasília/Fortaleza, Planaltina, DF, Brazil

L. Rusinamhodzi $(\bowtie) \cdot$ M. T. van Wijk $\cdot$ K. E. Giller

Plant Production Systems Group, Wageningen University,

P.O. Box 430, 6700 AK Wageningen, The Netherlands

e-mail: 1.rusinamhodzi@cgiar.org

M. C. Rufino

Sustainable Livestock Futures group,

International Livestock Research Institute,

P.O. Box 30709, Nairobi 00100, Kenya

J. Nyamangara

ICRISAT-Bulawayo,

Box 776, Bulawayo, Zimbabwe rainfall areas. But we observed no difference in system stability under those conditions. We observed a strong relationship between maize grain yield and annual rainfall. Our meta-analysis gave the following findings: (1) $92 \%$ of the data show that mulch cover in high rainfall areas leads to lower yields due to waterlogging; (2) $85 \%$ of data show that soil texture is important in the temporal development of conservation agriculture effects, improved yields are likely on well-drained soils; (3) $73 \%$ of the data show that conservation agriculture practices require high inputs especially $\mathrm{N}$ for improved yield; (4) $63 \%$ of data show that increased yields are obtained with rotation but calculations often do not include the variations in rainfall within and between seasons; (5) $56 \%$ of the data show that reduced tillage with no mulch cover leads to lower yields in semi-arid areas; and (6) when adequate fertiliser is available, rainfall is the most important determinant of yield in southern Africa. It is clear from our results that conservation agriculture needs to be targeted and adapted to specific biophysical conditions for improved impact.

Keywords Conservation agriculture - Maize grain yield . Meta-analysis · Stability analysis $\cdot$ Rain-fed conditions . Southern Africa

\section{Contents}

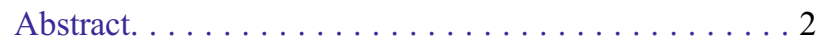

1. Introduction . . . . . . . . . . . . . . . . . . . .

2. Materials and methods . . . . . . . . . 10

2.1 Meta-analysis . . . . . . . . . . . . . . . . 10

2.2 Treatments for the meta-analysis . . . . . . . . . . . . . . . . .

2.3 Meta-analysis calculations . . . . . . . . . . . 16

2.4 Rainfall variability and maize yields . . . . . . . 17 
2.5 Yield stability analysis . . . . . . . . . . . . 18

3. Results and discussion. . . . . . . . . . . . . . 18

3.1 Summary statistics of weighted mean differences. . . . . . . . . . . . . . . . . 18

3.2 Reduced tillage, continuous maize. . . . . . . . . . 19

3.3 No-tillage, maize-legume rotation. . . . . . . . . . .20

3.4 No-tillage with mulch, continuous maize. . . . . . .22

3.5 Effect of mean annual rainfall and rainfall variability. . . . . . . . . . . . . . . . . . . .24

3.5.1 Effect of mean annual rainfall. . . . . . . . 24

3.5.2 Effect of rainfall variability. . . . . . . . . .26

3.6 Effect of soil texture. . . . . . . . . . . . . .28

3.7 Effect of nitrogen fertiliser input. . . . . . . . . . 29

3.8 Yield stability analysis. . . . . . . . . . . . .31

3.9 Lessons for southern Africa. . . . . . . . . . . . . 33

3.10 Challenges with long-term experiments. . . . . .34

4. Conclusions. . . . . . . . . . . . . . . . . . . . 35

References. . . . . . . . . . . . . . . . . . 37

\section{Introduction}

Knowledge of specific crop responses to tillage and surface crop residues as affected by soils, climate and $\mathrm{N}$ fertilisation is necessary in the selection of appropriate tillage and crop residue management strategies for improved crop production (Aina et al. 1991). Smallholder agriculture in Southern Africa is characterised by mouldboard ploughing and handhoeing that is often thought to lead to land degradation and excessive nutrient losses (Fowler and Rockstrom 2001; Knowler and Bradshaw 2007). To combat this scourge, conservation agriculture is being promoted through reduced tillage, permanent soil cover and crop rotations (FAO 2008). The effectiveness of conservation agriculture for controlling excessive water run-off and soil erosion is well documented (Adams 1966; Alberts and Neibling 1994; Choudhary et al. 1997; Lal 1998; Barton et al. 2004; Scopel et al. 2004), and it is expected that this contribution can be measured in terms of crop yield. Other benefits associated with conservation agriculture include reduction in the input costs for crop production and profit maximisation (Dumanski et al. 2006; Knowler and Bradshaw 2007).

Conservation agriculture emerged in the 1970s mostly in the USA and became an acceptable practice in the USA, Brazil, Argentina, Canada and Australia mainly because of its ability to combat increased soil erosion and land degradation and because of lower fuel costs (Dumanski et al. 2006; Harrington 2008). Conservation agriculture is mostly adopted by large-scale mechanized farmers with the concomitant widespread use of glyphosate for weed control (Derpsch 1999, 2005). Conservation agriculture was developed and adopted widely by farmers in South America mainly because it significantly reduced soil erosion, decreased labour costs and generally led to higher income and a better standard of living for the farmers (Ribeiro et al. 2007; Lahmar 2010).

Implementing conservation agriculture in Africa, particularly the semi-arid regions, presents challenges different from where conservation agriculture originated. In semiarid regions (300-500 $\mathrm{mm}$ annual rainfall), particularly Southern Africa, success of conservation agriculture depends on the ability of farmers to retain crop residues and to ensure adequate weed control (Giller et al. 2009). Farming systems are predominantly mixed crop-livestock systems with low crop productivity and most crop residues are grazed in situ by livestock or transported to the kraal to improve quantity and quality of manure (Murwira et al. 1995; Mapfumo and Giller 2001; Erenstein 2002; Zingore et al. 2007). Rainfall is unimodal and erratic with high variability both within and between seasons, and droughts are common (Challinor et al. 2007). Combined mechanical and hand weeding are the preferred and cheaper weed control methods, and use of herbicides is uncommon (Siziba 2007). Crop rotations are often non-systematic with maize grown continuously for 3-5 years and are aimed at exploiting residual fertility rather than at benefiting the following crops in the rational sequence (Mapfumo and Giller 2001). Fertiliser use is inadequate mainly due to high transaction costs and inefficiencies throughout the production and consumption chain (Quinones et al. 1997). On the other hand, the little fertiliser available is often not the correct type required for various crops and most farmers are not familiar with its correct usage (Sanginga and Woomer 2009).

Manipulating tillage and mulch management to improve water infiltration and reduce water loss from the soil surface in crop fields has potential to substantially improve crop yields and soil conditions in the semi-arid tropics (Hussain et al. 1999; Findeling et al. 2003; Tarkalson et al. 2006; Adekalu et al. 2007). Conventional tillage practices alter soil structure and increase porosity of the upper layer. This increases the initial water infiltration into the soil, but total infiltration is often decreased by subsoil compaction (Aina et al. 1991; Azooz and Arshad 1996; Gómez et al. 1999). Cultivated soils may lose a lot of rainfall as run-off and large amounts of soil through erosion (Duley 1940). Intensive rainfall on bare soil leads to surface sealing and soil compaction, resulting in localised waterlogging and poor soil infiltration (Castro et al. 2006). The mulch component of conservation agriculture controls soil erosion by reducing raindrop impact on the soil surface, decreasing the water runoff rate and increasing infiltration of rainwater (Lal 1989; Barton et al. 2004). Under semi-arid conditions, mulches also play an important role in conservation of soil water through reduced soil evaporation (Scopel et al. 2004). 
In theory, reduced tillage and surface cover increase soil water available for crop growth by increasing infiltration and by limiting run-off and evaporation losses (Fig. 1). However, mulching is not positive in all circumstances; under continuous rainfall, mulches have little effect on soil water status (Unger et al. 1991). Prolonged dry periods may also cause the benefits of mulching to diminish due to continued evaporation (Jalota and Prihar 1990). Intensive rainfall in mulched fields can cause waterlogging because of reduced evaporation (Araya and Stroosnijder 2010) leading to reduced soil aeration (Cannell et al. 1985).

Interactions between the components of conservation agriculture and their effects on crop yields are complex and often site-specific and long-term experiments are necessary to provide a better understanding. They provide unique information on the sustainability of crop production systems and the interactions between management practices and the broader environment (Powlson et al. 2006). Sustainability is defined as the ability of a system to maintain productivity despite major disturbances such as intensive stress or a large perturbation (Conway 1985; Hansen 1996). Practically, longterm experiments enable observations on changes in crop growth patterns and management effects on slow-moving factors such soil organic matter, which cannot be done in any other way (Jenkinson 1991; Mitchell et al. 1991). They are important for designing cropping systems with high and stable crop yields and low production risk (Raun et al. 1993; Stanger et al. 2008). We analysed maize grain yield data from rain-fed long-term studies on tillage and residue management from semi-arid to sub-humid environments. Maize grain yield is important because it is the staple food crop for most of Southern Africa where it constitutes more than $50 \%$ of the diet for most people and can be grown under widely varying rainfall and edaphic conditions (Eicher 1995; Smale 1995; Sileshi et al. 2008). We mainly focused on one of the pillars of sustainable land management, which is to maintain or enhance productivity (Dumanski and Smyth 1994). Crop yield is important because it is the most common and useful parameter used to evaluate the acceptability by farmers of any production practice (Gameda et al. 1997; Abeyasekera et al. 2002).

The objective of this paper was to use data from longterm studies to provide an understanding of the effects of long-term tillage and/or residue retention practices on maize grain yield under contrasting soil textures, crop rotation, $\mathrm{N}$ fertiliser input and climate through meta-analysis. An analysis of the relationship between annual rainfall variability and maize grain yield was also carried out using data from southern Africa. This meta-analysis was used to draw major lessons for southern Africa because in this region, there is a strong need for effective soil and water conservation practices to avert the effects of recurrent droughts. Analysing data from other regions provide an indication of the likely impact (ex ante) on food security of promoting reduced tillage and mulch-based cropping practices. It was also intended to understand the interactions between maize yield and rainfall, given its high variability under the climatic conditions of Southern Africa.

\section{Materials and methods}

\subsection{Meta-analysis}

Maize grain yield data were obtained from long-term studies ( $>5$ years) on tillage and crop residue management
Fig. 1 The major components of the conservation agriculture practice at the soil-atmosphere interface showing how tillage and mulch management affect infiltration, soil moisture availability and crop growth. Tillage alters soil structure and increase porosity of the upper layer and enhances the initial infiltration while mulch reduces raindrop impact on soil surface, increasing infiltration of rainwater and reducing evaporation

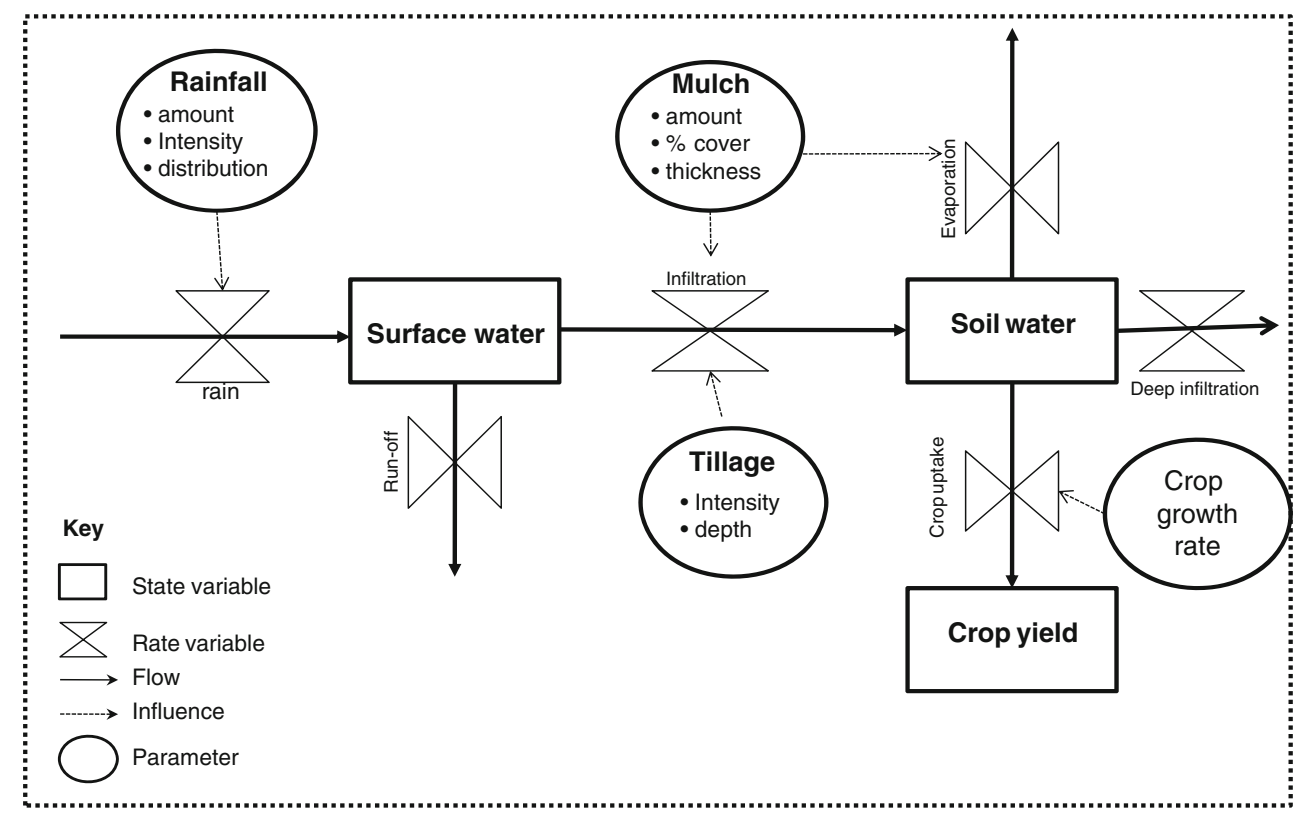


under rain-fed conditions established in semi-arid and subhumid environments from across the whole world. Treatments had to be from randomised plots with at least three replications. Studies (see Table 1) were obtained from refereed journals, book chapters or peer-reviewed conference proceedings through online searches. Our search was comprehensive including the following keywords and their combinations: conservation agriculture, long-term, reduced tillage, no-tillage, maize yield, corn yield, sub-humid, semi-arid, rain-fed, southern Africa. We also contacted key experts who are working on conservation agriculture. We collected information on climate (mainly rainfall), altitude, soil texture of the experimental site, agronomic management (rate of nitrogen fertiliser applied) as reported by the primary authors (Table 1). These factors were considered to have significant influence on the effect sizes. Data required for the meta-analysis were in the form of treatment mean $(\bar{X})$, its standard deviation $\left(S D_{\bar{X}}\right)$ and the number of replicates $(n)$ mentioned in the experimental design. Several authors presented statistical data in different formats such as standard error $\left(S E_{\bar{X}}\right)$ and coefficient of variation $(C V \%)$. These forms were converted to standard deviation $\left(S D_{\bar{X}}\right)$ using the following equations: $S D_{\bar{X}}=$ $S E_{\bar{X}} \times \sqrt{n}$ and $S D_{\bar{X}}=\left(\frac{C V \%}{100}\right) \times \bar{X}$.

Meta-analysis allows quantitative analyses of experimental results reported by other authors and the estimation of effect sizes (Glass 1976; Ried 2000; Rosenburg et al. 2000; Borenstein et al. 2009). The analysis increases the statistical power available to test hypotheses and differences in response between treatments under different environments (Gates 2002; Borenstein et al. 2009). The effect size found in each individual study can be considered an independent estimate of the underlying true effect size, subject to random variation. All studies contribute to the overall estimate of the treatment effect whether the result of each study is statistically significant or not. Data from studies with more precise measurements are given more weight, so they have a greater influence on the overall estimate (Gates 2002). However, meta-analysis has poten-
Table 1 The studies used in the meta-analysis, showing the country where the experiment was carried out, the duration of the experiment, the treatments, soil texture at the experimental site, mean annual precipitation (MAP) for the duration of experiment and nitrogen $(\mathrm{N})$ applied to the experiment

\begin{tabular}{|c|c|c|c|c|c|c|}
\hline Reference & Country & Treatments & Duration (years) & Soil texture & MAP & $\mathrm{N}$ application $\left(\mathrm{kg} \mathrm{ha}^{-1}\right)$ \\
\hline Wilhelm and Wortmann (2004) & USA & $\mathrm{CP}, \mathrm{NT}$ & 16 & Sandy loam & 720 & 113 \\
\hline Karlen et al. (1991) & USA & CP, NT & 12 & Loam & 1120 & 168,202 \\
\hline Griffith et al. (1988) & USA & $\mathrm{CP}, \mathrm{NT}$ & 12 & Silty clay Loam & 420 & 210,311 \\
\hline Linden et al. (2000) & USA & CP, NT, NTM & 12 & Silty loam & 820 & $0,100,200$ \\
\hline Lal (1997) & Nigeria & CP, NT, NTM & 8 & Sandy loam & 700 & 100 \\
\hline Vogel (1993) & Zimbabwe & $\mathrm{CP}, \mathrm{NT}$ & 9 & Sandy & 800 & 50,83 \\
\hline Moyo (2003) & Zimbabwe & $\mathrm{CP}, \mathrm{NT}$ & 9 & Sandy & 500 & 50,83 \\
\hline Nehanda (2000) & Zimbabwe & CP, NT & 8 & Clay & 800 & 50,83 \\
\hline Olson and Ebelhar (2009) & USA & $\mathrm{CP}, \mathrm{NT}$ & 10 & Silt loam & 600 & 218 \\
\hline Wilhelm et al. (1987) & USA & $\mathrm{CP}, \mathrm{NT}$ & 7 & Silty clay loam & 570 & $0,70,140$ \\
\hline Thiagalingam et al. (1996) & Australia & CP, NT & 5 & Loam & 900 & $0,20,40,80,160$ \\
\hline Iragavarapu and Randall (1995) & USA & $\mathrm{CP}, \mathrm{NT}$ & 11 & Clay loam & 1400 & 200 \\
\hline Acharya and Sharma (1994) & India & CP, NT, NTM & 6 & Clay loam & 2500 & 120 \\
\hline Sisti et al. (2004) & Brazil & $\mathrm{CP}, \mathrm{NT}$ & 6 & Clay & & 48,60 \\
\hline Jin et al. (2007) & China & CP, NTM & 8 & Silty loam & 700 & 150 \\
\hline Karunatilake et al. (2000) & USA & CP, NT & 8 & Clay loam & & - \\
\hline Mazzoncini et al. (2008) & Italy & CP, NT & 16 & Silty loam & 700 & 188 \\
\hline Dam et al. (2005) & Canada & CP, NT, NTM & 12 & Loamy sand & 430 & 180 \\
\hline Fischer et al. (1986) & Mexico & CP, NT, NTM, & 5 & Clay & 603 & 50,100 \\
\hline Rice et al. (1986) & USA & CP, NT & 21 & Silty loam & 550 & $0,84,168,336$ \\
\hline Ghuman and Sur (2001) & India & CP, NTM & 5 & Sandy loam & 920 & 80 \\
\hline Karlen et al. $(1994 a, b)$ & USA & NT, NTM & 10 & Silty loam & & 168,202 \\
\hline Ismail et al. (1994) & USA & CP, NT, NTM & 21 & Silty loam & & $0,84,168,336$ \\
\hline Nyagumbo (2002) & Zimbabwe & $\mathrm{CP}, \mathrm{NT}$ & 8 & Sandy & 800 & 180 \\
\hline Dick and Van Doren (1985) & USA & $\mathrm{CP}, \mathrm{NT}$ & 43 & Silty clay loam & 400 & 340 \\
\hline Govaerts et al. (2005) & Mexico & $\mathrm{CP}, \mathrm{NT}$ & 6 & Silty loam & 600 & 120 \\
\hline
\end{tabular}

$C P$ conventional ploughing, $N T$ no-tillage, $N T M$ no-tillage with mulch 
tial weaknesses due to publication bias and other biases that may be introduced in the process of locating, selecting and combining studies (Egger et al. 1997; Noble 2006). Publication bias is the tendency on the part of investigators, reviewers and editors to submit or accept manuscripts for publication based on the direction or strength of the study findings (Dickersin 1990). To overcome these challenges, our searches were carried out online in order to get results from all parts of the world as long as they originated from semi-arid and sub-humid environments. We identified the factors in our analysis such as mean annual precipitation, soil texture and $\mathrm{N}$ fertiliser input which could affect the effect sizes and employed the random effects model (Ried 2000).

\subsection{Treatments for the meta-analysis}

In our analysis, we were interested in treatments that could allow effects of tillage and mulch on maize grain yield to be disaggregated (Table 2). The effect of tillage was analysed by comparing conventional tillage and no-tillage treatments; therefore, conventional tillage was used as the control treatment. No-tillage without rotation was compared with no-tillage with rotation to determine the effect of rotation; thus, no-tillage without rotation was used as the control treatment. Similarly, effect of mulching was analysed by comparing no-tillage without mulch and no-

Table 2 A short description of the tillage treatments used for the evaluation of tillage and mulch effects on maize yield

\begin{tabular}{|c|c|}
\hline $\begin{array}{l}\text { Tillage management } \\
\text { option }\end{array}$ & Short description \\
\hline $\begin{array}{l}\text { Conventional tillage } \\
\text { (CT) }\end{array}$ & $\begin{array}{l}\text { Mouldboard ploughing is the major } \\
\text { means of seedbed preparation and weed } \\
\text { control; most crop residues are eaten by } \\
\text { livestock and the little left are buried in } \\
\text { the soil. The most widely practiced } \\
\text { tillage technique used by communal } \\
\text { farmers with animal draught power in } \\
\text { southern Africa. }\end{array}$ \\
\hline $\begin{array}{l}\text { No-tillage/reduced } \\
\text { tillage (NT) }\end{array}$ & $\begin{array}{l}\text { Practice of minimising soil disturbance, } \\
\text { ranges from reducing the number of } \\
\text { tillage passes, tillage depth or stopping } \\
\text { tillage completely. Weed control is } \\
\text { accomplished primarily with herbicides. }\end{array}$ \\
\hline $\begin{array}{l}\text { No-tillage }+ \text { rotation } \\
\text { (NTR) }\end{array}$ & $\begin{array}{l}\text { As described in (2) above. Main crop of } \\
\text { maize in a rotation sequence with } \\
\text { legumes such as soybean (Glycine max) } \\
\text { or cowpea (Vigna unguiculata (L.) } \\
\text { Walp). }\end{array}$ \\
\hline $\begin{array}{l}\text { No-tillage }+ \text { mulch } \\
\text { (NTM) }\end{array}$ & $\begin{array}{l}\text { No-tillage plus previous crop residues to } \\
\text { achieve at least } 30 \% \text { soil cover after } \\
\text { planting. Generally referred to as } \\
\text { conservation agriculture (CA) treatment. }\end{array}$ \\
\hline
\end{tabular}

tillage with mulch; therefore, no-tillage without mulch was the control treatment. Moderators of maize yield response were crop rotation, soil texture, mean annual precipitation and $\mathrm{N}$ input.

\subsection{Meta-analysis calculations}

In our analysis, we used the mean difference (Eq. 1.1) in yield between the treatment and control because of its ease of interpretation (Ried 2000). The yield difference is also more relevant when comparing potential gains to required investment and input costs (Sileshi et al. 2008). To obtain overall treatment effects across studies, the differences between treatment and control were weighted (Eq. 1.3). The weight given to each study was calculated as the inverse of the variance (Eq. 1.2). The random effects model was the most appropriate model to calculate effect sizes as it assumed that studies were drawn from different populations, and this could influence the treatment effect. Soil texture, nitrogen input, crop rotation and amount of seasonal rainfall were chosen as covariates and their effect tested on the magnitude of response (mean differences) each with a time component. Due to asymmetry in data distribution between treatments and covariates, conservation agriculture practices (NT, NTR and NTM) were combined together when analysing the effects of covariates. Rainfall was categorised using longterm mean annual of sites to form mean annual precipitation classes as low $(<600 \mathrm{~mm})$, medium $(600-1,000 \mathrm{~mm})$ and high $(>1,000 \mathrm{~mm})$ based on FAO guidelines (Fischer et al. 2001). Soil texture was categorised as clay, sandy, loamy and silt clay loam (Brown 2003), and nitrogen fertiliser input was

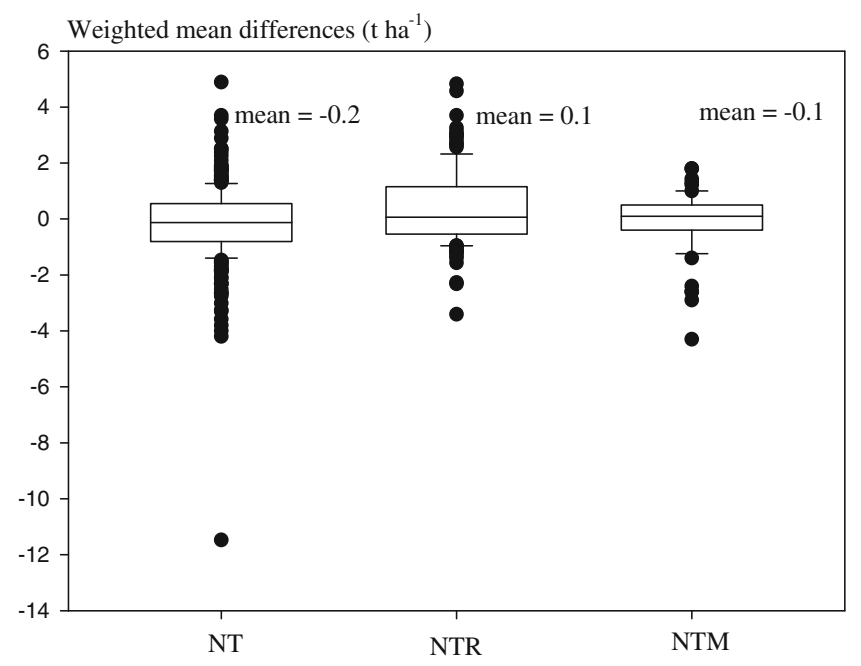

Fig. 2 Summary statistics of maize grain yield weighted mean differences $\left(\mathrm{t} \mathrm{ha}^{-1}\right)$ in the treatments used for the meta-analysis. The middle lines are the median values, data show that no-tillage with continuous maize had the largest range but the smallest mean. $N T$ no-tillage/reduced tillage, NTR no-tillage+rotation, NTM notillage + mulch 
categorised as low $\left(<100 \mathrm{~kg} \mathrm{ha}^{-1}\right)$ and high $\left(>100 \mathrm{~kg} \mathrm{ha}^{-1}\right)$ (Osmond and Riha 1996).

$$
\begin{aligned}
& \text { Mean difference }(M D)=\text { mean }_{\text {treated }}-\text { mean }_{\text {control }} \\
& \text { weight }_{i}=\frac{1}{\text { variance }_{i}}=\frac{1}{S D_{i}^{2}}
\end{aligned}
$$

$$
\begin{aligned}
& \text { Weighted mean difference }(W M D)_{\text {overall }} \\
& =\sum_{i=1}^{i=n}\left(\text { weight }_{i} \times M D\right) / \sum_{i=1}^{i=n} \text { weight }_{i} \\
& C I_{95 \%}=\text { mean }_{\text {overall }} \pm\left(1.96 \times\left(\text { variance }_{\text {overall }}\right)^{0.5}\right)
\end{aligned}
$$

$$
\text { Variance }_{\text {overall }}=\frac{1}{\sum_{i=1}^{i=n} \text { weight }_{i}}
$$

\subsection{Rainfall variability and maize yields}

In sub-Saharan Africa, when sufficient nutrients are available, rainfall variability (both within and across seasons) is the most critical determinant of crop yield (Waddington 1993; Phillips et al. 1998). In this region, $89 \%$ of cereal production is rainfed (Cooper 2004). We evaluated the relationship between maize yield and annual rainfall variability in southern Africa using non-linear regression (Bergamaschi et al. 2007). We used data from three sites with sub-humid climate where long-term conservation agriculture experiments were established in 1988: (1) the Institute of Agricultural Engineering $\left(17^{\circ} 42^{\prime} \mathrm{S}, 31^{\circ} 06^{\prime} \mathrm{E}, 1,600 \mathrm{~m}\right.$ above sea level and $18 \mathrm{~km}$ north of Harare), (2) Domboshawa Training Centre (17 $35^{\prime}$ $\mathrm{S}, 31^{\circ} 10^{\prime} \mathrm{E}, 1,600 \mathrm{~m}$ above sea level and $33 \mathrm{~km}$ north of Harare) and (3) Makoholi Research Station (19 $34^{\prime}$ S, 30 $47^{\prime}$ E, 1,200 $\mathrm{m}$ above sea level and $270 \mathrm{~km}$ south of Harare). The first site is characterised by deep, well-drained, red clay soils while Domboshawa Training Centre and Makoholi Research Station are characterised by inherently infertile granite-derived sandy soils (Nyamapfene 1991). Both Institute of Agricultural Engineering and Domboshawa Training Centre receive rainfall of about 750 to $1,000 \mathrm{~mm} /$ year but Makoholi Research Station receives between 450 and $650 \mathrm{~mm} /$ year (Vincent and Thomas 1960; Moyo 2003).

\subsection{Yield stability analysis}

A stable system shows a small change in response to changes in the environment (Lightfoot et al. 1987). We

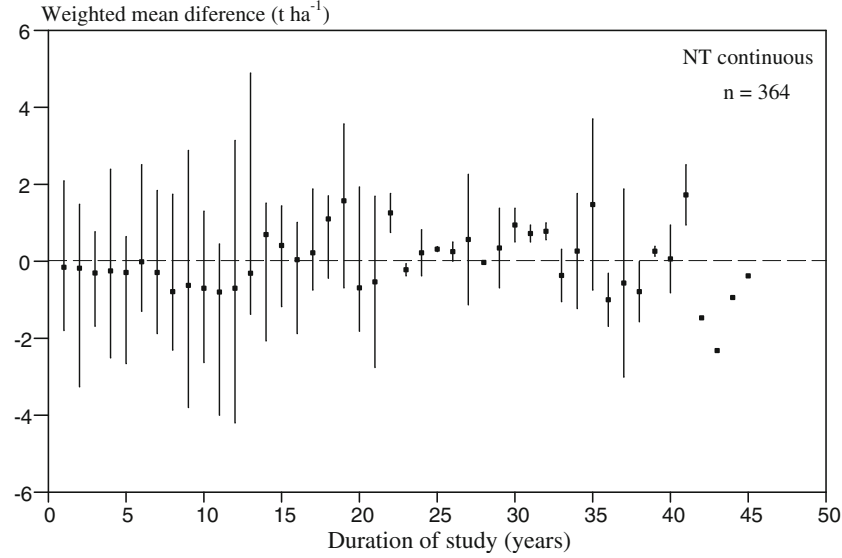

Fig. 3 Weighted mean differences in maize grain yield over time between continuous no-tillage and continuous conventional tillage. Effect sizes show yield benefits in some years but yield decreases in other years, overall there is no clear effect. NT no-tillage/reduced tillage

regarded each tillage practice as a system, and the stability of the system in this study is measured by linear regression of treatment yield against the environmental mean yield; the environmental mean is the average of all the treatments in a given year (Piepho 1998; Hao et al. 2007; Grover et al. 2009). A regression coefficient smaller than one indicates a higher stability (Bilbro and Ray 1976). The regression model is shown in Eq. 1.6:

$y_{i j}=\mu_{i}+\beta_{i} u_{j}+d_{i j}$

where $y_{i j}$ is the treatment mean of the $i$ th treatment at the $j$ th environment, $\mu_{i}$ is the $i$ th treatment mean in all environments, $\beta_{i}$ is a regression coefficient corresponding to the $i$ th treatment, $u_{j}$ is an effect of the $j$ th environment and $d_{i j}$ is a random deviation from the regression line (Eberhart and Russell 1966; Piepho 1998).

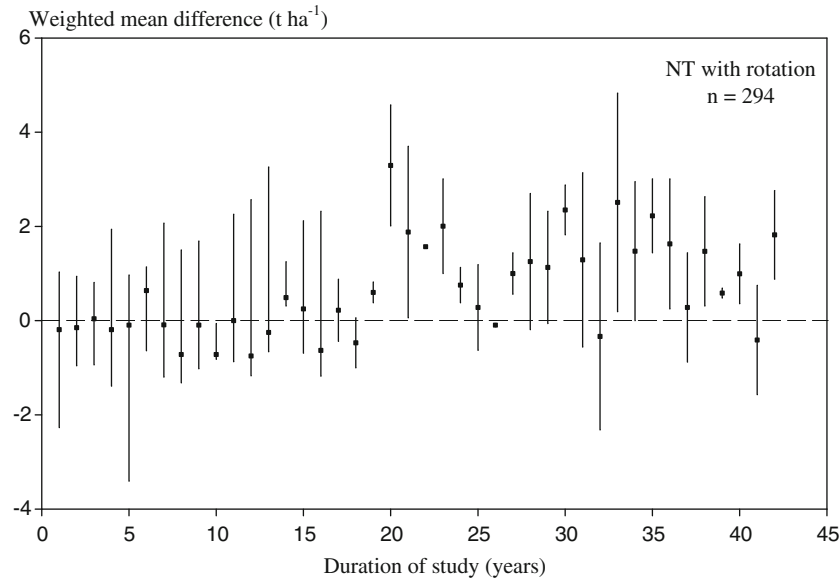

Fig. 4 Weighted mean differences in maize grain yield over time between no-tillage with rotation and no-tillage without rotation. Although effect sizes are generally positive, real yield benefits start after 20 years of production 


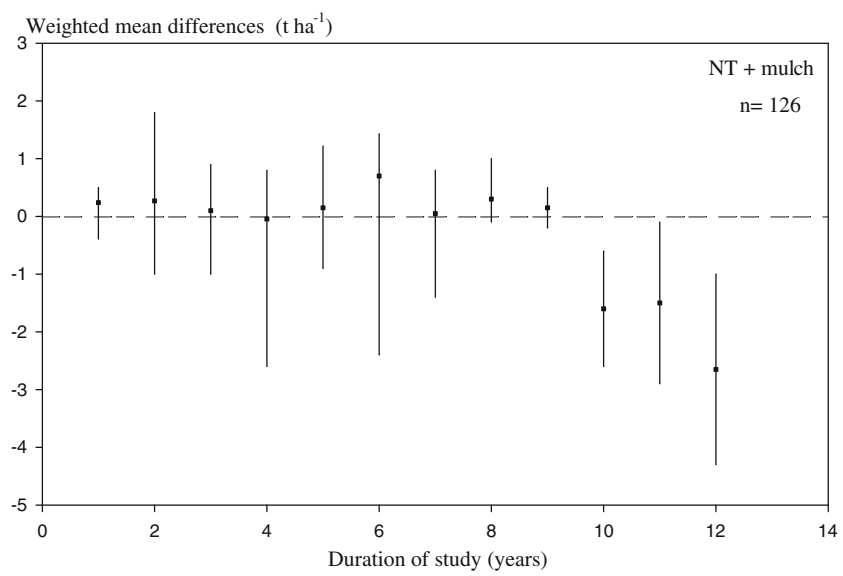

Fig. 5 Weighted mean differences in maize grain yield over time between continuous no-tillage with mulch and no-tillage without mulch

\section{Results and discussion}

\subsection{Summary statistics of weighted mean differences}

Summary statistics showed large variations in maize yield among the treatments across the regions considered (Fig. 2). Reduced tillage with rotation had a positive overall effect on maize yield while reduced tillage (with or without mulch) and continuous maize had negative overall effect on yield compared with the control. Lal (1997) observed that tillage treatments were only significant in three out of eight seasons but maize yield depended more on the amount of rainfall received and its distribution during the season. This observation clearly shows that besides tillage and mulch management, more factors are important for maize yield increases; thus, we explore these factors in the sections that follow.

\subsection{Reduced tillage, continuous maize}

There was no change in weighted mean differences in maize grain yield over time; therefore, no-tillage had no positive effect on maize yield compared with conventional tillage (Fig. 3). Results showed that in the first 10 years, crops yielded less than the conventional tillage practice. At the beginning of the experiment, reduced tillage practices often resulted in smaller yields than the control, but this was not true for all years. These results are similar to results of Kapusta et al. (1996) who reported no difference in yield between no-tillage and conventional ploughing on poorly drained soils after 20 years of continuous no-tillage. Dam et
Fig. 6 Weighted mean differences between conservation agriculture practices $(N T$ no-tillage/reduced tillage, NTR no-tillage+rotation, NTM no-tillage + mulch) and conventional tillage over time as affected by mean annual precipitation. a Effect sizes show clear yield benefits with time when annual rainfall is below $600 \mathrm{~mm}$. b Effect sizes do not show a clear trend in yield benefits when annual rainfall is between 600 and 1,000 mm. c Effect sizes show a clear decrease in maize yield under conservation agriculture when mean annual precipitation is above $1,000 \mathrm{~mm}$
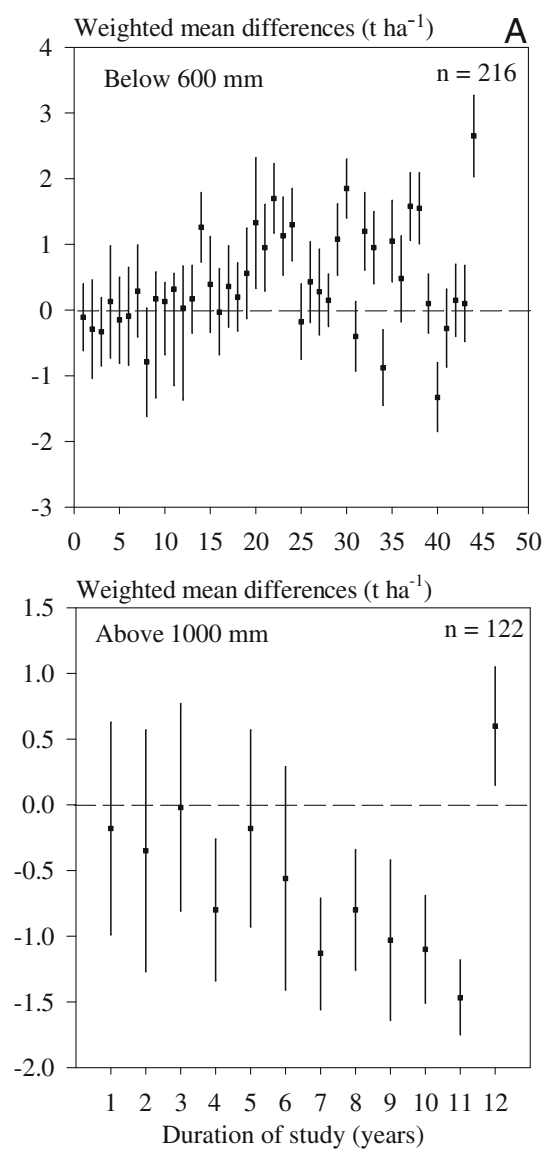

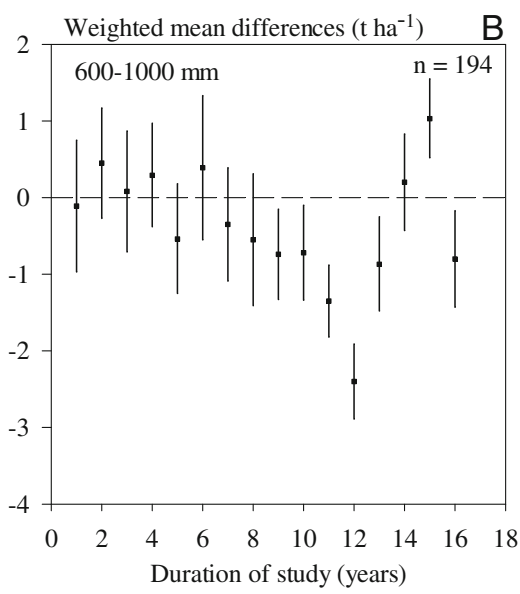


al. (2005) reported that after 11 years, maize yields were not affected by tillage and residue practices but climate-related differences seemed to have a greater influence on the variation in yields. When residues were completely removed, yield reductions for maize were attributed to decreased soil water storage and excessive surface soil temperatures, especially in climates where conditions of moisture stress occurred during the growing season (Doran et al. 1984). Evidence from Switzerland showed that ploughing could be dispensed under cool moist conditions without loss in yield for crops such as wheat and rape but with maize, no-tillage yielded $10 \%$ less than tillage treatments (Anken et al. 2004).

\subsection{No-tillage, maize-legume rotation}

There was an increase in yield in no-tillage with rotation over no-tillage without rotation as shown by the positive overall weighted mean difference (Fig. 4) in maize-legume rotations. Most of the studies reporting crop yields with rotation showed positive effects in no-tillage systems agreeing with the results of Karlen et al. (1991, 1994a, b), who reported that rotations are likely to produce greater yields across soil fertility regimes. Higher yield for no-tillage in rotation than in monocropping is attributed to a combined effect of multiple factors that include reduced pest infestations, improved water use efficiency, good soil quality as shown by increased organic carbon, greater soil aggregation, increased nutrient availability and greater soil biological activity (Van Doren et al. 1976; Griffith et al. 1988; Hernanz et al. 2002; Wilhelm and Wortmann 2004; Agyare et al. 2006; Kureh et al. 2006). Other authors report that there is often a larger increase in yield in low-yielding environments than in high-yielding environments (Lauer and Oplinger 1996; Porter et al. 1997). The larger yield increase of rotated crops is low-yielding environments means that this production strategy shows promise for most environments in southern Africa. The results of the meta-analysis suggest that rotation should be an integral component of tillage practices for supplying nutrients to maize (Francis and King 1988; Chikowo et al. 2004) and also for breaking pests and disease life cycles as found in other studies (Jordan and Hutcheon 2003; Sandretto and Payne 2007).

\subsection{No-tillage with mulch, continuous maize}

There was no effect of no-tillage + mulch on yield over the conventional tillage, and after 10 years, there even seems to
Fig. 7 The relationship between total annual rainfall and maize grain yield as affected by tillage practice from long-term sites in Zimbabwe. There was a strong correlation between the amount of rainfall and maize grain yield as rainfall accounted for on average $63 \%$ of the variation in all sites. $N T$ no-tillage/reduced tillage
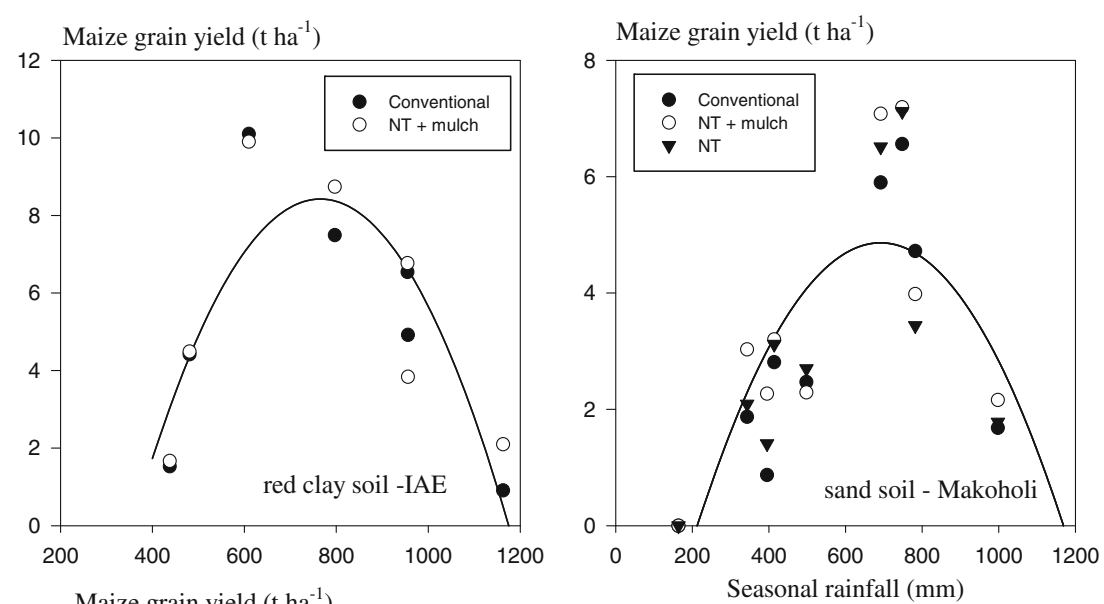
be strong negative effect (Fig. 5). These results are in contrast with the general belief that conservation agriculture effects emerge in the long term. Results from the Laikipia conservation agriculture project in Kenya show that maize yields were virtually the same under plots managed under conventional tillage and those managed under conservation agriculture (Kaumbutho and Kienzle 2007). Mulch cover associated with no-tillage practices promotes soil water retention (Blevins et al. 1971) and reduces soil temperature (Burrows and Larson 1962) which delays maize emergence and early-season growth. Some authors (Van Doren et al. 1976; Mupangwa et al. 2007) have also found that neither mulching nor tillage practice had a significant effect on maize grain yield on different soil textures and Lal (1997) reported a positive effect of no-tillage + mulch in only three of eight seasons. It has been observed that the effectiveness of mulch is limited in environments with little rainfall (Tolk et al. 1999). The lack of clear benefits on maize grain yield with mulch suggests that it may be better to allocate crop residues as livestock feed instead of keeping it for mulch. Probert (2007) did a modelling exercise using long-term experimental data and concluded that retaining increasing proportions of residues reduces evaporation and run-off but the long-term average yields show only small effects of residue retention on crop yields and the transpiration component of the water balance. Probert (2007) further observed that with no change in transpiration, the reductions in run-off and evaporation must be balanced by increases in drainage. These findings are further supported by a similar modelling exercise using data from the Brazilian Cerrados (Scopel et al. 2004). Vogel (1993) suggested that no-tillage in combination with tied ridging is the most suitable tillage technique for the sub-humid regions because it prevents water-logging and increased root depth, whereas mulching is likely to be the best conservation tillage technique for the semi-arid regions due mainly to reduced topsoil water losses.

\subsection{Effect of mean annual rainfall and rainfall variability}

\subsubsection{Effect of mean annual rainfall}

Maize yield was higher with conservation agriculture practices (NT, NTR and NTM) when mean annual precipitation was below $600 \mathrm{~mm}$ and lower when mean annual precipitation was above $1,000 \mathrm{~mm}$ (Fig. 6). This might be attributed to moisture conservation in low rainfall areas under conservation agriculture and compromised drainage in high rainfall areas. These results agree with
Fig. 8 Weighted mean differences between conservation agriculture practice (NT notillage/reduced tillage, $N T R$ no-tillage+rotation, NTM notillage + mulch) and conventional tillage over time as affected soil texture. a Effect sizes do not show any increase in yield over time in silt clay loam soils. $\mathbf{b}$ Effect sizes do not show any increase in yield over time in sandy soils. c Effect sizes show substantial increases in yield over time in loam soils. d Effect sizes show loss in yield over time in clay soils
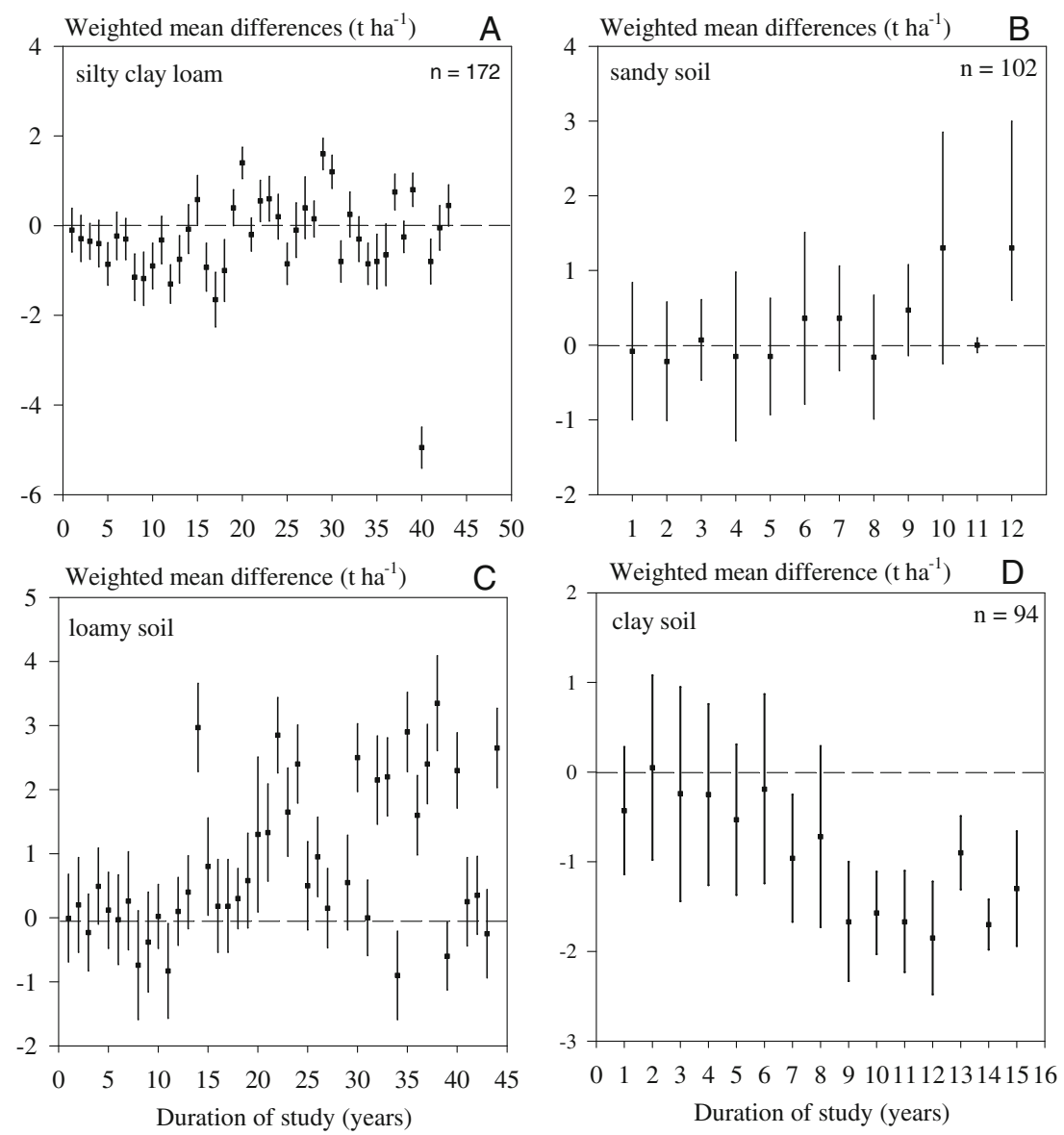
Fig. 9 Effect of nitrogen input on the weighted mean differences between conservation agriculture (NT no-tillage/ reduced tillage, NTR no-tillage + rotation, NTM no-tillage+ mulch) and conventional tillage over time. Effect sizes show yield increases when nitrogen input is above $100 \mathrm{~kg} / \mathrm{ha}$
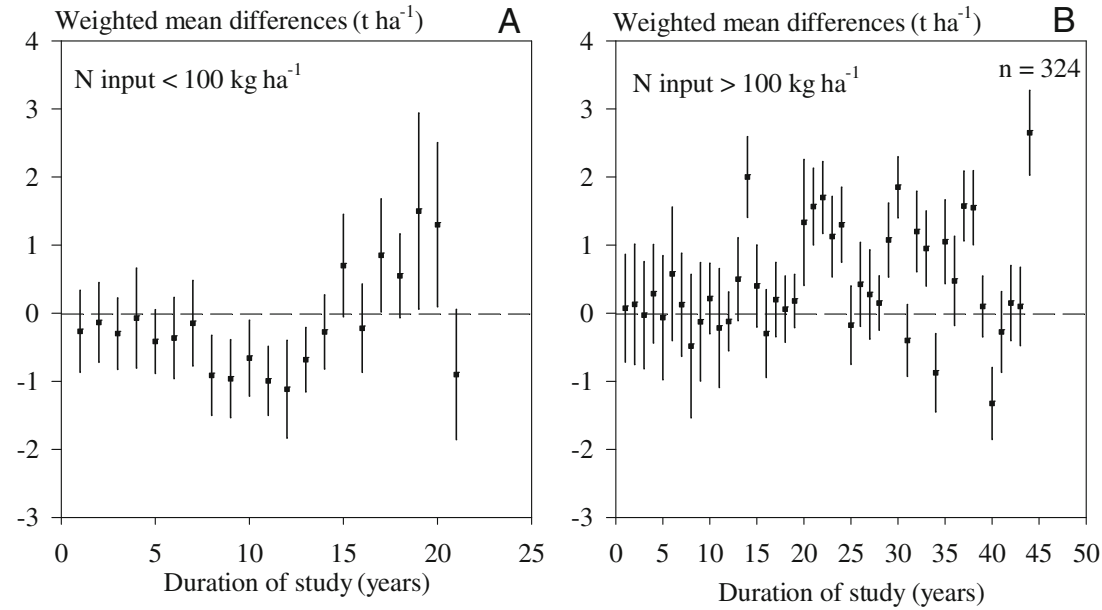

Hussain et al. (1999) who reported that yields under conservation agriculture practices were 5-20\% lower than under conventional tillage practices in wet years but were $10-100 \%$ higher in relatively dry year. Higher crop yield with the conservation agriculture practice than with conventional tillage in a dry year was also reported by Lueschen et al. (1991). Temporal variability in yield is mainly affected by environmental factors with precipitation having the strongest effect ( $\mathrm{Hu}$ and Buyanovsky 2003; Mallory and Porter 2007; Grover et al. 2009).

\subsubsection{Effect of rainfall variability}

Variation in total seasonal rainfall across seasons was responsible for major yield fluctuations across treatments in the three experiments of the dataset that were conducted in Zimbabwe (Fig. 7). Rainfall was highly variable across sites and across seasons, at Domboshawa, rainfall varied between 438 and $1,396 \mathrm{~mm}$ with a mean value of $823 \mathrm{~mm}$. It caused low yields across all treatments especially in 1989/90, 1991/92 (drought year) and 1996/97. At the Institute of Agricultural Engineering, rainfall ranged between 481 and 1,163 mm with a mean of $889 \mathrm{~mm}$. At Makoholi, rainfall was low but variation between seasons was very high (between 164 and $998 \mathrm{~mm}$ ) with a mean of $559 \mathrm{~mm}$. In two seasons of contrasting total rainfall, the conventional tillage practice had considerably higher yields than the mulched and reduced tillage treatments, suggesting the absence of benefits of tillage when extreme weather events occur. The low yield during the high rainfall years could be attributed to water-logging that affected nutrient uptake and crop growth (Griffith et al. 1988). The water conservation effect of mulch on maize yield under low rainfall was not observed during the drought of 1991/1992 (Nehanda and Munyati 1999; Moyo 2003). The temporal development of conservation agriculture effects in these three sites seems to be affected more by the amount of seasonal rainfall and soil texture rather than by tillage and mulch management practices. At Domboshawa and Makoholi, both sites characterised by sandy soils, recorded virtually no grain yield during drought years. There are greater chances of conservation agriculture effects developing at the Institute of Agricultural Engineering, which is characterised by a combination of fertile red clay soils and good seasonal rainfall averaging $850 \mathrm{~mm}$ in most seasons. The build-up of conservation agriculture effects on sandy soils is a challenge because sandy soils readily lose soil quality during continuous cropping due to compaction, loss of organic matter and acidification (Juo et al. 1996).

\subsection{Effect of soil texture}

Analysis with soil texture and duration of experiment showed that in clay soils weighted mean differences were mostly negative but were positive in both loam and sandy soils
Table 3 Linear regression equations and $r^{2}$ values for tillage practice maize grain yield means for clay and sandy soils

\begin{tabular}{llllr}
\hline Soil texture & Tillage treatment & Regression equation & $r^{2}$ & Slope $P>/ \mathrm{t} /$ \\
\hline Clay & Conventional & $y=0.49+1.01 x$ & 0.94 & $<0.0001$ \\
& No-till & $y=-0.246+1.01 x$ & 0.93 & $<0.0001$ \\
& No-till+mulch & $y=0.045+1.06 x$ & 0.92 & $<0.0001$ \\
Sand & Conventional & $y=-0.005+1.001 x$ & 0.99 & $<0.0001$ \\
& No-till & $y=-0.180+1.045 x$ & 0.98 & $<0.0001$ \\
& No-till+mulch & $y=0.259+0.942 x$ & 0.99 & $<0.0001$ \\
\hline
\end{tabular}


Fig. 10 Linear regressions for tillage practice maize grain yield means on the environmental maize grain yield means for clay and sandy soils. Slopes were compared among treatments at $P<0.05$
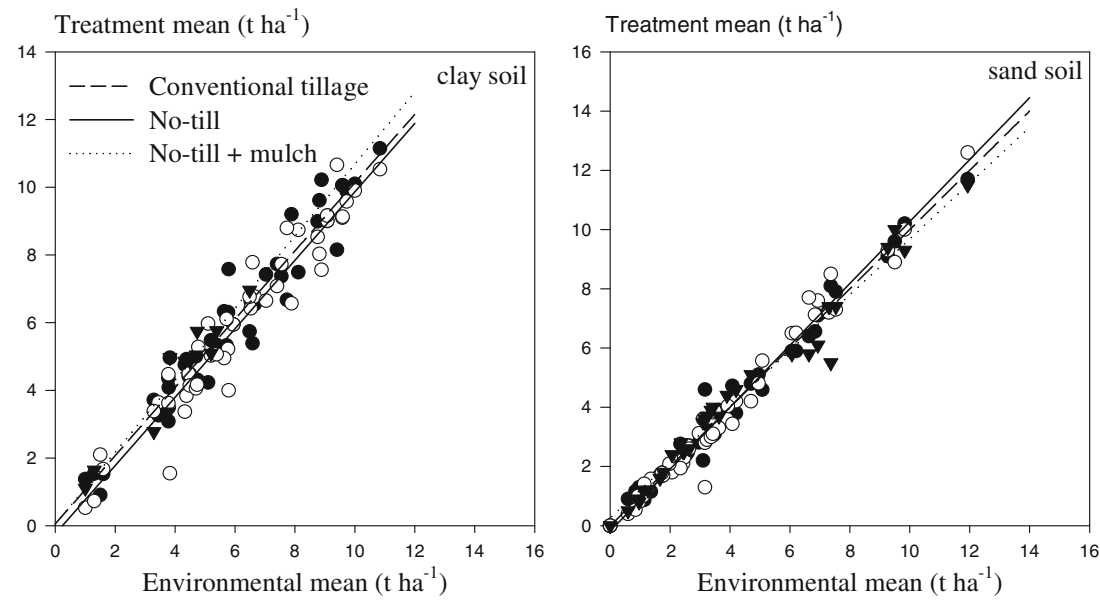

(Fig. 8). There was no significant difference between conservation agriculture treatments (NT, NTR and NTM) and conventional tillage on maize yield on silt clay loams with time. However, there was an improvement in maize grain yield on loamy and sandy soils. Dick and Van Doren (1985) also reported yield reductions of maize associated with no-tillage on heavy clay, very poorly drained soils and suggested crop rotations and use of disease resistant cultivars as possible solutions. However, Van Doren et al. (1976) reported that maize grain yields are insensitive to tillage over a wide range of soil textures, cropping systems, climate conditions and experiment durations as long as equal plant densities and adequate weed control were maintained. The reduction in crop yields on poorly drained soils under conservation agriculture was also reported by Griffith et al. (1988). Increased yields on well-drained soils are attributed to more efficient use of water and improved physical properties (Griffith et al. 1986). Low yields in poorly drained soils are attributed to allelopathy (Yakle and Cruse 1984) and plant pathogens (Tiarks 1977). Kapusta et al. (1996) reported that continuous maize production under no-tillage is most successful on well-drained soil, rather than on either imperfectly or poorly drained soil, especially under wet soil conditions. It has also been suggested that maize monocropping has drastic adverse effects on soil quality and crop yield especially under conditions of low traffic and no-tillage with mulching (Lal 1997). Most soils in southern Africa have biophysical limitations (poor nutrient concentrations, acidity, coarse texture) that limit biomass accumulation; therefore, combinations of legume rotations and mineral nitrogen fertilisation is the most viable option for sustainable agriculture in this region (Chikowo et al. 2004).

\subsection{Effect of nitrogen fertiliser input}

Nitrogen is often the most limiting nutrient for maize produced in the tropics (Osmond and Riha 1996). At nitrogen fertiliser applications of below $100 \mathrm{~kg} \mathrm{~N}^{-1}$, there were fewer yield advantages of conservation agriculture over conventional tillage, but more yield benefits were obtained with high applications of above $100 \mathrm{~kg} \mathrm{~N} / \mathrm{ha}$ (Fig. 9). The results agree with Díaz-Zorita et al. (2002) who reported in a review that maize yields were increased more by nitrogen fertilisation than tillage under sub-humid and semi-arid regions of Argentina. These results show that conservation agriculture practices are input intensive; therefore, improved crop yields under conservation agriculture depend on the ability of farmers to use fertiliser in sufficient quantities and correct proportions. The current average fertiliser use by smallholder farmers in Africa is at $8 \mathrm{~kg} \mathrm{ha}^{-1}$ (Groot 2009), and considerable effort is required to improve its use (Sanginga and Woomer 2009). While the fertiliser rates categories considered are quite high and most farmers in Southern Africa cannot afford such rates, fertiliser remains important to alleviate nutrient constraints.

Most crop residues in semi-arid areas are derived from maize, millets and sorghum, which are traditionally known for their poor quality due to high $\mathrm{C} / \mathrm{N}$ ratios, generally greater than 60 (Cadisch and Giller 1997; Handayanto et al.

Table 4 Linear regression equations and $r^{2}$ values for the tillage system maize grain yield means on the environmental maize grain yield means for short- and long-term trials

\begin{tabular}{lllll}
\hline Duration & $\begin{array}{l}\text { Tillage } \\
\text { treatment }\end{array}$ & $\begin{array}{l}\text { Regression } \\
\text { equation }\end{array}$ & $r^{2}$ & Slope $P>/ \mathrm{t} /$ \\
\hline$<10$ years & Conventional & $y=-0.132+1.03 x$ & 0.97 & $<0.0001$ \\
& No-till & $y=-0.043+0.99 x$ & 0.96 & $<0.0001$ \\
& No-till+mulch & $y=0.496+0.953 x$ & 0.95 & $<0.0001$ \\
$>10$ years & Conventional & $y=-0.060+0.99 x$ & 0.91 & $<0.0001$ \\
& No-till & $y=0.0393+1.009 x$ & 0.91 & $<0.0001$ \\
& No-till+mulch & $y=0.236+0.970 x$ & 0.82 & $<0.0001$ \\
\hline
\end{tabular}

$P>/-\mathrm{t} /$ is the probability of a greater absolute value of the slope $(/ \mathrm{t} /)$ 
Fig. 11 Linear regressions for the tillage practice maize grain yield means on the environmental maize grain yield means for short term $(<10$ years) and long term ( $>10$ years). Slopes were compared among treatments at $P<0.05$
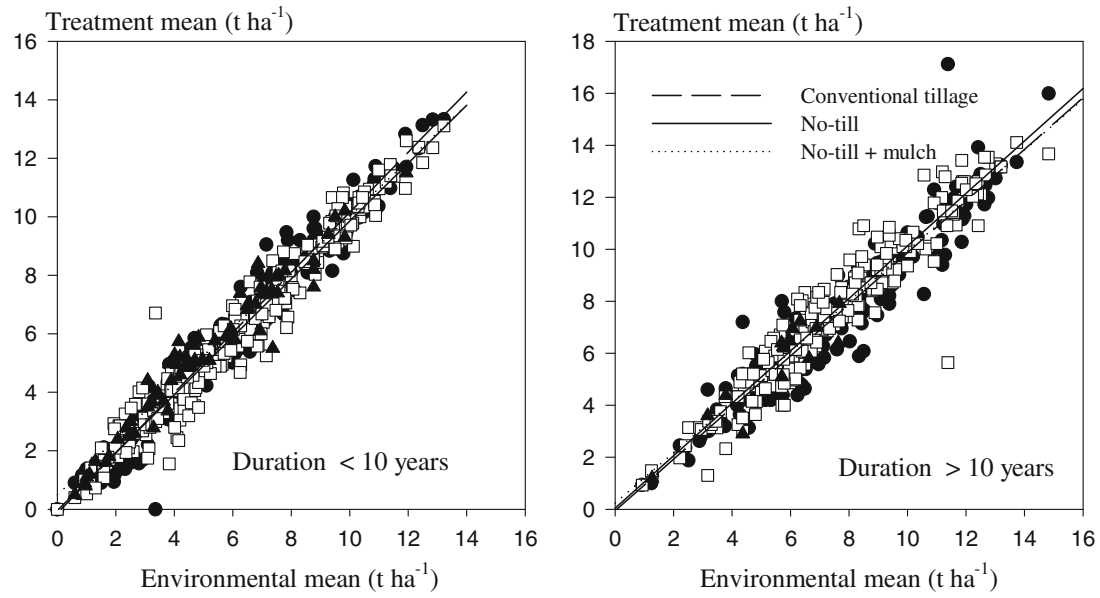

1997). Although crop residues are often on the soil surface, there is a greater chance of partial incorporation and decomposition as the season progresses (Parker 1962). The wide $\mathrm{C} / \mathrm{N}$ ratio and the relatively large amounts of readily decomposable carbon compounds leads to prolonged nitrogen immobilisation by micro-organisms, rendering the nitrogen unavailable for crop growth in the short term (Giller et al. 1997) thus high nitrogen inputs are required when poor quality crop residues are used as mulch.

\subsection{Yield stability analysis}

There was no treatment effect on stability as a regression between environmental and treatment mean for soil texture (Table 3 and Fig. 10) and for duration of experiment (Table 4 and Fig. 11) with regression coefficients ranging from 0.94 to 1.06 and $r^{2}$ values ranging between 0.92 and 0.99 . The regression analysis for no-tillage with mulch practice had a smaller regression coefficient in sandy soils showing an advantage of mulch-based systems to optimise moisture availability in soils of poor drainage. Our hypothesis that reduced tillage and residue retention leads to more stable yields was not supported by the data.

\subsection{Lessons for southern Africa}

Competition for crop residue use, low fertiliser use, non-use of herbicides, labour shortage, erratic rainfall, lack of crop rotations and poor soils combine to offer many challenges for the practice of conservation agriculture among smallholder farmers in Southern Africa (Siziba 2007; Giller et al. 2009). It is clear from the meta-analysis that the success of conservation agriculture in improving crop yields depends on appropriate targeting to climatic and edaphic conditions with adequate inputs (fertiliser and herbicides). Farmers are unlikely to adopt all the conservation agriculture practices and success will not come from the pre-packed technologies alone but from how farmers adapt and apply them depending on resources availability, production objectives (benefits) and biophysical circumstances (Ojiem et al.
Fig. 12 a, b Simple factorial design to unravel the effects of tillage, mulch and rotation on crop yields. Major plots should be established side by side with one being for cereal-legume rotation and the other being for legume-cereal rotation, this allows the study of both cereal or legume continuous monocropping effects
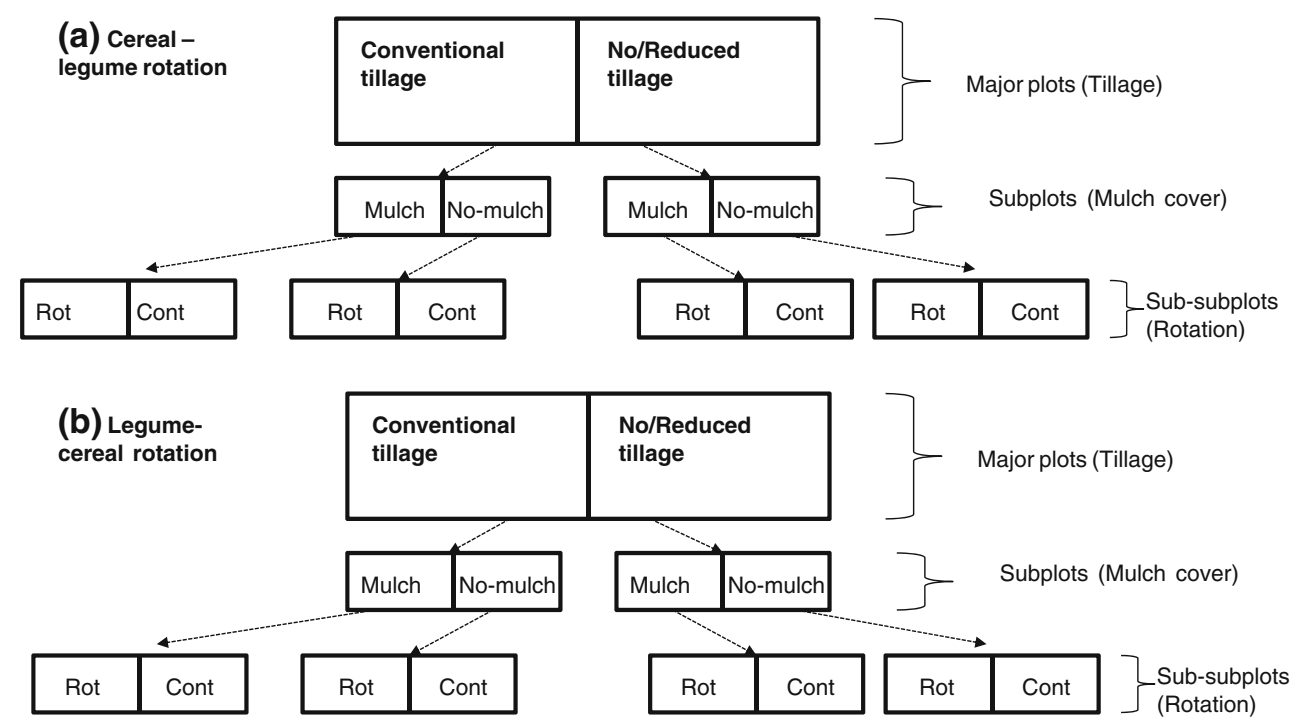
2006). In situations of crop-livestock integration where competition for crop residue use is strong, intercropping with grain legumes can be a viable strategy to achieve surface cover because the legume will cover the area between rows of the main crop and help conserve moisture (Scott et al. 1987). In cases were linkages to markets for grain legumes can be secured, legume production can be an excellent opportunity for farmers to increase land size allocated for legumes and improve rotation with main cereal crops. Alternatively planting basins can be an efficient method of moisture conservation if they can be maintained after weeding operations (Mupangwa et al. 2007, 2008).

\subsection{Challenges with long-term experiments}

Long-term trials are designed to help identify and recommend production systems with beneficial effects on the environment as well as crop productivity across variable environments over time. However, in long-term trials when the cropping system has approached a new equilibrium, it is difficult to attribute effects to particular factors as the interactions between the factors (tillage, mulch, rotation, soil texture and rainfall) involved are so subtle and sitespecific that proper experimental designs are required. Sources of variations where crop residues are retained increase as yield varies across seasons to the extent that the effect of mulch will not be explicitly identified. Results from this meta-analysis suggest that yields decline due to continuous monoculture effects and this is more pronounced on sandy soils of low inherent fertility (Lal 1997). These monoculture effects will become more pronounced with time, diminishing the influence of tillage practices on maize yield. Reduction in maize grain yield with continuous maize and no-tillage have been recorded and attributed to unknown underground effects, which need further research (Wolfe and Eckert 1999; Fischer et al. 2002). Well-designed long-term experiments are still desirable across different agro-ecological conditions to unravel the effects of mulch, tillage and rotation on maize grain yield. We propose a simple experimental design (Fig. 12) that we expect can be used to identify the effects of different components. We also propose that the analysis of studies across seasons should take into consideration variability in rainfall to avoid overestimating treatment effects.

\section{Conclusions}

The factors considered in our analysis covered most of the environments where rain-fed agriculture is practiced and gives us a basis to draw the following conclusions. Positive impacts of moisture conservation on crop yield in soils of poor drainage are likely to occur in low rainfall environments, and maize yielded less in no-tillage without rotation compared with conventional tillage but more when rotation was practised. Results clearly showed that the successful practice of conservation agriculture required high inputs, especially nitrogen fertiliser. Under rain-fed agricultural conditions where total rainfall and its distribution is important for crop production, yield stability analysis results showed that under drought or too much rainfall, no treatments can offset the effects of these extreme conditions. Incentives for abandoning the plough still exist through savings in fuel, labour, and wear and tear of farm implements; however, this needs to be quantified in a separate analysis. Very few studies if any can disaggregate the effects of the three principles (reduced tillage, mulch cover and crop rotation) on maize grain yield; thus, welldesigned long-term experiments are still desirable across different agro-ecological conditions to unravel the effects of mulch, tillage and rotation on maize grain yield. Improving maize yields under conservation agriculture in Southern Africa depends on the ability of farmers to practice crop rotation and given that, on average, they plant legumes on $5 \%$ of the land, we propose that conservation agriculture be repackaged to reflect the diversity of farming systems and other biophysical and socio-economic considerations for improved impact. Our analyses have shown that success of conservation agriculture in Southern Africa depends on the promotion of other good agronomic practices such as targeted fertiliser application, timely weeding and crop rotations.

Acknowledgements We are most grateful and indebted to a number of authors, and we would like to make a special mention to Professor Waren A. Dick, Nithya Janakiraman, Sindhu Jagadamma and Adelaide Moyo-Munodawafa for making available raw data from their longterm studies. Financial support from TSBF-CIAT Harare through the Sub-Saharan Challenge Program's Conservation Agriculture Taskforce grant is greatly appreciated. Marc Corbeels acknowledges financial support from the European Commission through the CA2Africa Project.

Open Access This article is distributed under the terms of the Creative Commons Attribution Noncommercial License which permits any noncommercial use, distribution, and reproduction in any medium, provided the original author(s) and source are credited.

\section{References}

Abeyasekera S, Ritchie JM, Lawson-McDowall J (2002) Combining ranks and scores to determine farmers' preferences for bean varieties in southern Malawi. Exp Agr 38:97-109

Acharya CL, Sharma PD (1994) Tillage and mulch effects on soil physical environment, root growth, nutrient uptake and yield of maize and wheat on an Alfisol in north-west India. Soil Till Res 32:291-302 
Adams JE (1966) Influence of mulches on runoff, erosion, and soil moisture depletion. Soil Sci Soc Am J 30:110-114

Adekalu KO, Olorunfemi IA, Osunbitan JA (2007) Grass mulching effect on infiltration, surface runoff and soil loss of three agricultural soils in Nigeria. Bioresource Technol 98:912-917

Agyare WA, Clottey VA, Mercer-Quarshie H, Kombiok JM (2006) Maize yield response in a long-term rotation and intercropping systems in the Guinea Savannah zone of Northern Ghana. J Agron 5:232-238

Aina PO, Lal R, Roose EJ (1991) Tillage methods and soil and water conservation in West Africa. Soil Till Res 20:165-186

Alberts EE, Neibling WH (1994) Influence of crop residues on water erosion. In: Unger PW (ed) Managing agricultural residues. Lewis Publishers, Chelsea, pp 19-39

Anken T, Weisskopf P, Zihlmann U, Forrer H, Jansa J, Perhacova K (2004) Long-term tillage system effects under moist cool conditions in Switzerland. Soil Till Res 78:171-183

Araya A, Stroosnijder L (2010) Effects of tied ridges and mulch on barley (Hordeum vulgare) rainwater use efficiency and production in Northern Ethiopia. Agr Water Manage 97:841-847

Azooz RH, Arshad MA (1996) Soil infiltration and hydraulic conductivity under long-term no tillage and conventional tillage systems. Can J Soil Sci 76:143-152

Barton AP, Fullen MA, Mitchell DJ, Hocking TJ, Liu L, Bo ZW, Zheng Y, Xia ZY (2004) Effects of soil conservation measures on soil erosion rates and crop productivity on subtropical Ultisols in Yinnan Province. China Agr Ecosyst Environ 104:343-357

Bergamaschi H, Wheeler TR, Challinor AJ, Comiran F, Heckler BMM (2007) Maize yield and rainfall on different spatial and temporal scales in Southern Brazil. Pesqui Agropecu Bras 42:603-613

Bilbro JD, Ray LL (1976) Environmental stability and adaptation of several cotton cultivars. Crop Sci 16:821-824

Blevins RL, Cook D, Phillips SH, Phillips RE (1971) Influence of notillage on soil moisture. Agron J 54:19-23

Borenstein M, Hedges LV, Higgins JPT, Rothstein HR (2009) Introduction to Meta-analysis. Wiley, London

Brown RB (2003) Soil texture. Institute of Food and Agricultural Sciences. University of Florida, Florida, p 8

Burrows WC, Larson WE (1962) Effect of amount of mulch on soil temperature and early growth of corn. Agron J 54:19-23

Cadisch G., Giller K.E. (1997) (Eds.) Driven by Nature: Plant Residue Quality and Decomposition. CAB International, Wallingford, UK.

Cannell RQ, Belford RK, Blackwell PS, Govi G, Thomson RJ (1985) Effects of waterlogging on soil aeration and on root and shoot growth and yield of winter oats (Avena sativa L.). Plant Soil $85: 361-373$

Castro G, Romero P, Gomez JA, Fereres E (2006) Rainfall redistribution beneath an olive orchard. Agri Water Manage 86:249-258

Challinor A, Wheeler T, Garforth C, Craufurd P, Kassam A (2007) Assessing the vulnerability of food crop systems in Africa to climate change. Climatic Change 83:381-399

Chikowo R, Mapfumo P, Nyamugafata P, Giller KE (2004) Maize productivity and mineral $\mathrm{N}$ dynamics following different soil fertility management practices on a depleted sandy soil in Zimbabwe. Agr Ecosyst Environ 102:119-131

Choudhary MA, Lal R, Dick WA (1997) Long-term tillage effects on runoff and soil erosion under simulated rainfall for a central Ohio soil. Soil Till Res 42:175-184

Conway GR (1985) Agro-ecosystem analysis. Agr Admin 20:31-55

Cooper P (2004) Coping with climatic variability and adapting to climate change: Rural water management in dry-land areas. International Development Research Centre, London

Dam RF, Mehdi BB, Burgess MSE, Madramootoo CA, Mehuys GR, Callum IR (2005) Soil bulk density and crop yield under eleven consecutive years of corn with different tillage and residue practices in a sandy loam soil in central Canada. Soil Till Res 84:41-53

Derpsch R (1999) Frontiers in conservation tillage and advances in conservation practice. In: D.E. Stott, R.H. Mohtar, G.C. Steinhardt (Eds.), $10^{\text {th }}$ International Soil conservation Organization: Sustaining the Global Farm, Purdue University pp. 248-254.

Derpsch R (2005) The extent of conservation agriculture adoption worldwide: Implications and impact. World Congress on Conservation Agriculture: Linking Production, Livelihoods and Conservation, Nairobi

Díaz-Zorita M, Duarte GA, Grove JH (2002) A review of no-till systems and soil management for sustainable crop production in the sub-humid and semiarid Pampas of Argentina. Soil Till Res 65:1-18

Dick WA, Van Doren DM Jr (1985) Continuous tillage and rotation combinations effects on corn, soybean, and oat yields. Agron J $77: 459-465$

Dickersin K (1990) The existence of publication bias and risk factors for its occurrence. J Am Med Assoc 263:1385-1389

Doran JW, Wilhelm WW, Power JF (1984) Crop residue removal and soil productivity with no-till corn, sorgum, and soybean. Soil Sci Soc Am 48:640-645

Duley FL (1940) Surface factors affecting the rate of intake of water by soils. Soil Sci Soc Am 4:60-64

Dumanski J, Smyth AJ (1994) The issues and challenges of sustainable land management. In: Wood RC, Dumanski J (eds) Proc. International Workshop on Sustainable Land Management for the 21st Century. Agricultural Institute of Canada, Ottawa, p 381

Dumanski J, Peiretti R, Benetis J, McGarry D, Pieri C (2006) The paradigm of conservation tillage. Proceedings of World Association of Soil and Water Conservation, FAO, Rome, pp 58-64

Eberhart SA, Russell WA (1966) Stability parameters for comparing varieties. Crop Sci 6:36-40

Egger M, Smith GD, Phillips AN (1997) Meta-analysis: principles and procedures. Brit Med J 315:1533-1537

Eicher CK (1995) Zimbabwe's maize-based Green Revolution: Preconditions for replication. World Dev 23:805-818

Erenstein O (2002) Crop residue mulching in tropical and semitropical countries: An evaluation of residue availability and other technological implications. Soil Till Res 67:115-133

FAO, 2008. http://www.fao.org/ag/ca/.

Findeling A, Ruy S, Scopel E (2003) Modelling the effects of a partial residue mulch on runoff using a physically based approach. J Hydrol 275:49-66

Fischer G, Van Velthuizen HT, Nachtergaele FO (2001) Global agroecological zones assessment for agriculture in the $21^{\text {st }}$ century. FAO, Austria

Fischer RA, Santiveri F, Vidal IR (2002) Crop rotation, tillage and crop residue management for wheat and maize in the sub-humid tropical highlands: II. Maize and system performance. Field Crop Res 79:123-137

Fowler R, Rockstrom J (2001) Conservation tillage for sustainable agriculture: An agrarian revolution gathers momentum in Africa. Soil Till Res 61:93-108

Francis CA, King JW (1988) Cropping systems based on farmderived, renewable resources. Agr Syst 27:67-75

Gameda S, Dumanski J, Acton D (1997) Farm level indicators of sustainable land management for the development of decision support systems. International workshop on geo-information for sustainable land management, The Netherlands

Gates S (2002) Review of methodology of quantitative reviews using meta-analysis in ecology. J Anim Ecol 71:547-557

Ghuman BS, Sur HS (2001) Tillage and residue management effects on soil properties and yields of rain-fed maize and wheat in a sub-humid subtropical climate. Soil Till Res 58:1-10 
Giller KE, Cadisch G, Ehaliotis C, Adams E, Sakala WD, Mafongoya PL (1997) Building soil nitrogen capital in Africa. In: Buresh RJ, Sanchez PA, Calhoun F (eds) Replenishing Soil Fertility in Africa. Soil Science Society of America Special Publication No. 51, USA, pp 81-95

Giller KE, Witter E, Corbeels M, Tittonell P (2009) Conservation agriculture and smallholder farming in Africa: The heretics' view. Field Crop Res 114:14-23

Glass GV (1976) Primary, secondary, and meta-analysis of research. Educ Res 5:3-8

Gómez JA, Giráldez JV, Pastor M, Fereres E (1999) Effects of tillage method on soil physical properties, infiltration and yield in an olive orchard. Soil Till Res 52:167-175

Govaerts B, Sayre KD, Deckers J (2005) Stable high yields with zero tillage and permanent bed planting? Field Crop Res 94:33-42

Griffith DR, Mannering JV, Box JE (1986) Soil and moisture management with reduced tillage. In: Sprague MA, Triplett GB (eds) No-tillage and surface tillage in Indiana. Wiley, New York

Griffith DR, Kladivko EJ, Mannering JV, West TD, Parsons SD (1988) Long-term tillage and rotation effects on corn growth and yield on high and low organic matter, Poorly Drained Soils. Agron J 80:599-605

Groot JJR (2009) Update of fertiliser supply and demand - sub Saharan Africa. IFA Africa Forum. IDFC, Egypt

Grover KK, Karsten HD, Roth GW (2009) Corn grain yields and yield stability in four long-term cropping systems. Agron J 101:940-946

Handayanto E, Giller KE, Cadisch G (1997) Regulating N release from legume tree prunings by mixing residues of different quality. Soil Biol Biochem 29:1417-1426

Hansen JW (1996) Is agricultural sustainability a useful concept? Agr Syst 50:117-143

Hao MD, Fan J, Wang QJ, Dang TH, Guo SL, Wang JJ (2007) Wheat grain yield and yield stability in a long-term fertilization experiment on the Loess Plateau. Pedosphere 17:257-264

Harrington LW (2008) A brief history of conservation agriculture in Latin America, South Asia and Sub-Saharan Africa Conservation Agriculture Newsletter PACA

Hernanz JL, López R, Navarrete L, Sanchez-Giron V (2002) Longterm effects of tillage systems and rotations on soil structural stability and organic carbon stratification in semiarid central Spain. Soil Till Res 66:129-141

$\mathrm{Hu}$ Q, Buyanovsky G (2003) Climate effects on corn yield in Missouri. J Appl Meteorol 42:1626-1635

Hussain I, Olson KR, Ebelhar SA (1999) Impacts of tillage and no-till on production of maize and soybean on an eroded Illinois silt loam soil. Soil Till Res 52:37-49

Iragavarapu TK, Randall GW (1995) Yield and nitrogen uptake of monocropped maize from a long-term tillage experiment on a poorly drained soil. Soil Till Res 34:145-156

Ismail I, Blevins RL, Frye WW (1994) Long-term no-tillage effects on soil properties and continuous corn yields. Soil Sci Soc Am J 58:193-198

Jalota SK, Prihar SS (1990) Bare-soil evaporation in relation to tillage. In: Stewart BA (ed) Advances in Soil Science., pp 187-216

Jenkinson DS (1991) The Rothamsted long-term experiments: Are they still of use. Agron J 83:2-10

Jin H, Hongwen L, Xiaoyan W, McHugh AD, Wenying L, Huanwen G, Kuhn NJ (2007) The adoption of annual subsoiling as conservation tillage in dryland maize and wheat cultivation in northern China. Soil Till Res 94:493-502

Jordan VWL, Hutcheon JA (2003) Influence of cultivation practices on arable crop diseases, in: Titi A.E. (Ed.), Soil tillage in agroecosystems. CRC Press

Juo ASR, Franzluebbers K, Dabiri A, Ikhile B (1996) Soil properties and crop performance on a kaolinitic Alfisol after 15 years of fallow and continuous cultivation. Plant Soil 180:209-217
Kapusta G, Krausz RF, Matthews JL (1996) Corn yield is equal in conventional, reduced, and no tillage after 20 years. Agron $\mathrm{J}$ $88: 812-817$

Karlen DL, Berry EC, Colvin TS, Kanwar RS (1991) Twelve-year tillage and crop rotation effects on yields and soil chemical properties in northeast Iowa. Commun Soil Sci Plan 22:1985-2003

Karlen DL, Wollenhaupt NC, Erbach DC, Berry EC, Swan JB, Eash NS, Jordahl JL (1994a) Crop residue effects on soil quality following 10-years of no-till corn. Soil Till Res 31:149-167

Karlen DL, Wollenhaupt NC, Erbach DC, Berry EC, Swan JB, Eash NS, Jordahl JL (1994b) Long-term tillage effects on soil quality. Soil Till Res 32:313-327

Karunatilake U, van Es HM, Schindelbeck RR (2000) Soil and maize response to plow and no-tillage after alfalfa-to-maize conversion on a clay loam soil in New York. Soil Till Res 55:31-42

Kaumbutho P, Kienzle J (2007) (Eds.) Conservation agriculture as practised in Kenya: two case studies. African Conservation Tillage Network (ACT), Centre de Coopération Internationale de Recherche Agronomique pour le Développement (CIRAD), Food and Agriculture Organization of the United Nations (FAO), Nairobi, Paris, Rome.

Knowler D, Bradshaw B (2007) Farmers' adoption of conservation agriculture: A review and synthesis of recent research. Food Policy 32:25-48

Kureh I, Kamara AY, Tarfa BD (2006) Influence of cereal-legume rotation on Striga control and maize grain yield in farmers' fields in the Northern Guinea savanna of Nigeria. J Agr Rural Dev Trop Subtrop 107:41-54

Lahmar R (2010) Adoption of conservation agriculture in Europe: Lessons of the KASSA project. Land Use Policy 27:4-10

Lal R (1989) Conservation tillage for sustainable agriculture: tropics versus temperate environments. Adv Agron 42:85197

Lal R (1997) Long-term tillage and maize monoculture effects on a tropical alfisol in western Nigeria. I. Crop yield and soil physical properties. Soil Till Res 42:145-160

Lal R (1998) Mulching effects on runoff, soil erosion and crop response on alfisols in western Nigeria. J Sustain Agr 11:135-154

Lauer J, Oplinger E (1996) How important is crop rotation in "stress" environments? Wisconsin Crop Manager. Wisconsin Corn Agronomy, Wisconsin, pp 43-45

Lightfoot CWF, Dear KBG, Mead R (1987) Intercropping sorghum with cowpea in dryland farming systems in Botswana. II. Comparative stability of alternative cropping systems. Exp Agr 23:435-442

Linden DR, Clapp CE, Dowdy RH (2000) Long-term corn grain and stover yields as a function of tillage and residue removal in east central Minnesota. Soil Till Res 56:167-174

Lueschen WE, Evans SD, Ford JH, Hoverstad TR, Kanne BK, Orf JH, Stienstra WC, Warnes DD, Hicks DR (1991) Soybean production as affected by tillage in a corn and soybean management system: I. Cultivar response. J Prod Agric 4:571-579

Mallory EB, Porter GE (2007) Potato yield stability under contrasting soil management strategies. Agron J 99:501-510

Mapfumo P, Giller KE (2001) Soil fertility management strategies and practices by smallholder farmers in semi-arid areas of Zimbabwe. ICRASAT/FAO, India

Mazzoncini M., Di Bene C., Coli C.A., Risaliti R., Bonari E. (2008) Long-term tillage and nitrogen fertilisation effects on maize yield and soil quality under rain-fed Mediterranean conditions: a critical perspective, in: Christensen B.T., Petersen J., Schacht M. (Eds.), Long-term field experiments - a unique platform, Proc. 407 NJF Askov, Denmark, pp. 13-17.

Mitchell CC, Westerman RL, Brown JR, Peck TR (1991) Overview of long-term agronomic research. Agron J 83:24-29

Moyo A (2003) Assessment of the effect of soil erosion on nutrient loss from granite-derived sandy soils under different tillage 
systems in Zimbabwe. Ph.D. Thesis, University of Zimbabwe, Harare, Zimbabwe.

Mupangwa W, Twomlow S, Walker S, Hove L (2007) Effect of minimum tillage and mulching on maize (Zea mays L.) yield and water content of clay and sandy soils. Phys Chem Earth 32:1127-1134

Mupangwa W, Twomlow S, Walker S (2008) The influence of conservation tillage methods on soil water regimes in semi-arid southern Zimbabwe. Phys Chem Earth 33:762-767

Murwira HK, Swift, MJ, Frost, PGH (1995) Manure as a key resource in sustainable agriculture, in: Powell, J.M., Fernández-Rivera, S., Williams, T.O., Renard, C. (Eds.), Livestock and sustainable nutrient cycling in mixed farming systems of sub-Saharan Africa. Proc. Int. Conf. International livestock center for Africa (ILCA), Addis Ababa, Ethiopia, 22-26 November 1993. Technical papers, vol. II: pp 131-148.

Nehanda G (2000) The effects of three animal-powered tillage systems on soil-plant-water relations and maize cropping in Zimbabwe. Department of Soil Science and Agricultural Engineering. University of Zimbabwe, Harare, p 260

Nehanda G, Munyati M (1999) Conservation farming with drought in mind. Swedish Cooperative Centre- SADC Centre of Communication and Development, Harare, p 75

Noble JH (2006) Meta-analysis: Methods, strengths, weaknesses, and political uses. J Lab Clin Med 147:7-20

Nyagumbo I (2002) The effects of three tillage systems on seasonal water budgets and drainage of two Zimbabwean soils under maize. PhD Thesis University of Zimbabwe, Harare, Zimbabwe.

Nyamapfene K (1991) Soils of Zimbabwe. Nehanda, Zimbabwe, pp 75-79

Ojiem JO, de Ridder N, Vanlauwe B, Giller KE (2006) Socioecological niche: a conceptual framework for integration of legumes in smallholder farming systems. International $\mathrm{J} \mathrm{Agr}$ Sustain 4:79-93

Olson K, Ebelhar SA (2009) Impacts of conservation tillage systems on long-term crop yields. J Agron 8:14-20

Osmond DL, Riha SJ (1996) Nitrogen fertilizer requirements for maize produced in the tropics: A comparison of three computerbased recommendation systems. Agr Syst 50:37-50

Parker DT (1962) Decomposition in the field of buried and surfaceapplied cornstalk residue. Soil Sci Soc Am J 26:559-562

Phillips JG, Cane M, Rosenzweig C (1998) ENSO, seasonal rainfall patterns and simulated maize yield variability in Zimbabwe. Agr Forest Meteorol 90:39-50

Piepho HP (1998) Methods for comparing the yield stability of cropping systems - A review. J Agron Crop Sci 180:193-213

Porter PM, Lauer JG, Lueschen WE, Ford JH, Hoverstad TR, Oplinger ES, Crookston RK (1997) Environment affects the corn and soybean rotation effect. Agron J 95:233-244

Powlson DS, Poulton P, Macdonald AJ, Bingqiang Z, (2006) Longterm agricultural experiments: The Necessity for Change and the Need for Continuity. $18^{\text {th }}$ World Congress of Soil Science, Philadelphia, Pennsylvania, USA.

Probert ME (2007) Modelling minimum residue thresholds for soil conservation benefits in tropical, semi-arid cropping systems. ACIAR, Canberra, Technical Reports

Quinones MA, Borlaug NE, Dowswell CR (1997) A fertilizerbased green revolution for Africa. In: Buresh RJ, Sanchez PA, Calhoun F (eds) Replenishing Soil Fertility in Africa. Soil Science Society of America Special Publication 51, USA, pp $81-95$

Raun WR, Barreto HJ, Westerman RL (1993) Use of stability analysis for long-term soil fertility experiments. Agron J 85:159-167

Ribeiro MFS, Denardin JE, Bianchini A, Ferreira R, Flores CA, Kliemann HJ, Kochhann RA, Mendes IC, Miranda GM,
Montoya L, Nazareno N, Paz C, Peiretti R, Pillon CN, Scopel E, Skora NF (2007) Comprehensive inventory and assessment of existing knowledge on sustainable agriculture in the Latin American platform of KASSA. In: Lahmar R, Arrue JL, Denardin JE, Gupta RK, Ribeiro MFF, de Tourdonnet S (eds) Knowledge Assessment and Sharing on Sustainable Agriculture. CIRAD, Montpellier, p 58

Rice CW, Smith MS, Blevins RL (1986) Soil nitrogen availability after long-term continuous no-tillage and conventional tillage corn production. Soil Sci Soc Am J 50:1206-1210

Ried K (2000) Interpreting and understanding meta-analysis graphs: A practical guide. Aust Fam Physician 35:635-638

Rosenburg MS, Adams DC, Gurevitch J (2000) Metawin. Statistical Software for Meta-Analysis, Version 2. Sinauer Associates Inc, USA

Sandretto C, Payne J (2007) Soil management and conservation, in: Wiebe K., Gollehon N. (Eds.) Agricultural resources and environmental indicators. Nova Science Publishers.

Sanginga N, Woomer PL (2009) (Eds.) Integrated soil fertility management in Africa: Principles, practices and developmental process. Tropical Soil Biology and Fertility Institute of the International Centre for Tropical Agriculture, Nairobi.

Scopel E, Silva FAMD, Corbeels M, Affholder F, Maraux F (2004) Modelling crop residue mulching effects on water use and production of maize under semi-arid and humid tropical conditions. Agronomie 24:383-395

Scott TW, Mt. Pleasant J, Burt RF, Otis DJ (1987) Contributions of ground cover, dry matter, and nitrogen from intercrops and cover crops in a corn polyculture system. Agron J 79: 792-798

Sileshi G, Akinnisfesi FK, Ajayi OC, Place F (2008) Meta-analysis of maize yield response to woody and herbaceous legumes in subSaharan Africa. Plant Soil 307:1-19

Sisti CPJ, Dos Santos HP, Kohhann R, Alves BJR, Urquiaga S, Boddey RM (2004) Change in carbon and nitrogen stocks in soil under 13 years of conventional or zero tillage in southern Brazil. Soil Till Res 76:39-58

Siziba S (2007) Assessing the adoption of conservation agriculture in Zimbabwe's smallholder sector. Institute of Agricultural Economics and Social Sciences in the Tropics and Sub-tropics. University of Hohenheim, Hohenheim

Smale M (1995) Maize is life: Malawi's delayed Green Revolution. World Dev 23:819-831

Stanger FT, Lauer JG, Chavas JP (2008) The profitability and risk of long-term cropping systems featuring different rotations and nitrogen rates. Agron J 100:105-113

Tarkalson DD, Hergert GW, Cassman KG (2006) Long-term effects of tillage on soil chemical properties and grain yields of a dryland winter wheat-sorghum/corn-fallow rotation in the Great Plains. Agron J 98:26-33

Thiagalingam K, Dalgliesh N, Gould N, McCown R, Cogle A, Chapman A (1996) Comparison of no-tillage and conventional tillage in the development of sustainable farming systems in the semi-arid tropics. Aust J Exp Agr 36:995-1002

Tiarks AE (1977) Causes of increased corn root rot infection of continuous corn in no-tillage Hoytville clay loam in Northeastern Ohio. Ohio State University, Columbus

Tolk JA, Howell TA, Evett SR (1999) Effect of mulch, irrigation, and soil type on water use and yield of maize. Soil Till Res 50:137147

Unger PW, Stewart BA, Parr JF, Singh RP (1991) Crop residue management and tillage methods for conserving soil and water in semi-arid regions. Soil Till Res 20:219-240

Van Doren DM, Triplett GB, Henry JE (1976) Influence of long-term tillage, crop rotation, and soil type combinations on corn yield. Soil Sci Soc Am J 40:100-105 
Vincent V, Thomas RG (1960) An agricultural survey of southern Rhodesia: Part I: The Agroecological Survey". Government Printer, Salisbury, p 345

Vogel H (1993) Tillage effects on maize yields, rooting depth and soil water and water content on sandy soils in Zimbabwe. Field Crop Res 33:367-384

Waddington SR (1993) Overview of the current situation and previous impact of adaptive agricultural research on southern Africa. In: Craswell ET, Simpson J (eds) ACIAR/SACCAR Workshop on Soil Fertility and Climatic Constraints in Dryland Agriculture. ACIAR Canberra, Harare

Wilhelm WW, Wortmann CS (2004) Tillage and rotation interactions for corn and soybean grain yield as affected by precipitation and air temperature. Agron J 96:425-432
Wilhelm WW, Schepers JS, Mielke LN, Doran JW, Ellis JR, Stroup WW (1987) Dryland maize development and yield resulting from tillage and nitrogen fertilization practices. Soil Till Res 10:167-179

Wolfe AM, Eckert DJ (1999) Crop sequence and surface residue effects on the performance of no-till corn grown on a poorly drained soil. Agron J 91:363-367

Yakle GA, Cruse RM (1984) Effects of fresh and decomposing corn plant residue extracts on corn seeding development. Soil Sci Soc Am J 48:1143-1146

Zingore S, Murwira HK, Delve RJ, Giller KE (2007) Influence of nutrient management strategies on variability of soil fertility, crop yields and nutrient balances on smallholder farms in Zimbabwe. Agr Ecosyst Environ 119:112-126 